\title{
Soomlase elu kujutamine pärimuslikus ajaloos
}

\section{Pauliina Latvala}

Uue aastatuhande künnisel on huvitav küsida, kuidas soomlased mõtestavad mööduvat 20. sajandit. Kuidas inimene on üle elanud ühiskondlikud ja kultuurimuutused ning kuidas see peegeldub tema suguvõsa- ja perepärimuses? Soome Kirjanduse Selts korraldas 1997. aastal üleriikliku pärimuskogumise võistluse «Suvun suuri kertomus» (Suguvõsa suur jutustus, arhiivilühend SKS.SUKU), mille eesmärk oli pärimusliku ajaloo kaudu välja selgitada suguvõsa ja kodukoha tähendus tänapäeva inimese jaoks. Kogumisvõistluse tulemusena laekus üle 700 kirjaliku vastuse. Järgnevalt tutvustangi 20. sajandi Soome ajaloo kajastamist selle kogu põhjal.

\section{Pere minevikku peegeldava pärimuse seos ajalooga}

Pere minevikust jutustava pärimuse kujunemisel kehtivad samad põhimõtted, mis ametliku ajaloo kujunemiselgi. Mõlemad luuakse teatud kontekstis ja teatud vaatepunktist. Perepärimus moodustub jutustatud ja üksikisiku tasandil kogetud ajaloost, mida vahendatakse oma ja teiste mälestuste kaudu. Seppo Knuuttila järgi (1994: 23) on siin probleem selles, et jutustamise käigus muudetakse minevikku ja luuakse nii uut tegelikkust. Käesolevas artiklis käsitletakse kirjapandud mälestusi (vt Apo 1995: 176), kus korrastatakse meenutused ehk pisut süstematiseeritumalt kui suulises jutustuses. Tõenäoliselt on vastajal kirjutades rohkem meeles nii ametliku kui ka mitteametliku ajaloo kategooriad, millest kumbki kujundab jutustusele omad spetsiifilised raamid ja eeskujud. Mitteametlikuks ajalooks peetakse ennekõike suulist ajaloolist pärimust, aga ka selle kirjalikku esitust. Seda pärimust võib võtta kui ajalugu täiendavat tõlgendust. Ajalugu on peetud ühiskonna mäluks. Uurimismaterjal osutab sellele, et tegemist on valikulise mäluga. Isiklikud mälestused ja kogemused, erinev suhtumine samadesse ajajärkudesse, sündmustesse ja inimestesse on teadmiste mitmekülgseks allikaks mineviku mõtestamisel.

Sageli esineb pärimuses tõeline ja mäletatav minevik nostalgilise ning müütilisena. Selle põhjuseks on alateadlik unustamine kõrvaliste mõjutuste tõttu. Jutustus on alati valikuline, sisaldades jutustaja väärtushinnanguid, hoiakuid ja arusaamu mineviku sündmustest. Näiteks, kui uurida täpsemalt ühe väikese tööstuspiirkonna suulist pärimusajalugu, oleksid sama põlvkonna eri ametialade või erinevate majanduslik-sotsiaalsete kihtide esindajate jutustused kindlasti erinevad. Näiteks: tehase juhi - tööliste jutustused; töölise abikaasa - tööstusjuhi naise või mõisa laste - rentniku laste meenutused jne. Niisamuti erinevad üksteisest näiteks 1918. aasta kodusõjast nii ametlikud arusaamad kui ka valgete ja punaste mälestused. (vt Peltonen 1996: 242).

Pereajalugu sisaldava pärimuse folkloristlik uurimine annab ajaloo mõistmisele laiema perspektiivi. See on abiks eritasandi kultuuriilmingute jälgimisel. Uurides pere- ja suguvõsajutte, tulevad esile ka aja jooksul toimuvad muutused sugulussuhetes ning nende tähenduses, muutused pereliikmete rollijaotuses. Niisamuti on võimalik uurida, miks jutustatakse minevikust korduvalt ning seda, mil viisil ajalugu periodiseeritakse. 
Vaid üks osa perepärimusest on jutud neist isikutest, keda jutustaja on ise kohanud. Kellest siis saavad perepärimuse jututegelased? Perepärimuses lähtutakse neist aspektidest, mille kaudu jutustaja mõistab kõige paremini iseenda tausta ja identiteeti. Nii võib jutu peategelane olla vanaema, kellest on isikuloolisi mälestusi, aga ka 17. sajandil elanud mees, keda peetakse suguvõsa esiisaks.

Huvi möödunud sajandite argielu vastu on mõistagi suur ja suguvõsa põlvnemisloo uurimises püütakse jõuda ajas võimalikult kaugele. Soomlaste kasvavast huvist mineviku päevavalgele toomise vastu kõneleb näiteks seegi, et 1970. aastatest saadik on suguvõsa-kokkutulekute arv mitmekordistunud ja 1990. aastate lõpul on Soome ainus maa maailmas, kus on jõutud selleni, et talletada kirikuraamatud internetis (Spoof 1994: 79).

Kuidas pärimusjutud 20. sajandist peegeldavad üldisi teadmisi ajaloost? Kas perepärimus erineb sellest? Kas pärimusmaterjalist tajutav minevikujutustus peegeldab aega katkematu ja ühtlasena, või kehtivad soome kultuuris mineviku visandamiseks ja periodiseerimiseks spetsiifilised kujutamismallid? 20. sajandist kõnelevad kirjalikud pärimusjutustused kajastavad peaasjalikult järgmisi sündmusi: sõjad (Kodusõda 1918. aastal, Talve- ja Jätkusõda 1939-1945), väljaränne Ameerikasse, siirdumine maalt linna ja linnastumisega kaasnenud elulaadi muutused.

\section{Väljaränne Ameerikasse perepärimuse teemana}

Sõdadele eelnenud aastakümnetel ja ka sõja ajal (1870-1944) on registreeritud ligikaudu 400000 väljarännanud soomlast. Üle poolte neist alustasid rännet Pohjanmaalt, kus 19. sajandi lõpul oli kõrge sündivus. Sealse õigustava järgi päris talu vanem poeg, nooremad õed-vennad pidid muid võimalusi otsima (Korkiasaari \& Söderling 1994: 250-251). Väljarännet tõlgendati ühiskonna tasandil ja üksikisiku tasandil üsna erinevalt. Rahvusliku ideoloogia järgi tähendas maalt lahkumine moraalset ja majanduslikku kaotust. Väljarändest huvitatud noored samastasid aga Ameerikat muutustega ja tulevikuväljavaadete avardumisega (Haapala 1992: 29). Ameerikasse väljarändamisega seostub sageli soomlaste poliitilist aktiivsust kujundav aspekt: soomlased asusid elama tööstusaladele, see tugevdas aatelist organiseerumist. Soome tagasi tulnud töölised tõid kodukanti kodanikuõigustest kantud ideid ja käitumismalle (Korkiasaari \& Söderling 1994: 251).

Peamiselt Põhja-Ameerikasse suundunud väljarände tausta on iseloomustatud väga erinevalt. Ametlik ajalugu peab väljarände peapõhjusteks järgmisi asjaolusid: Ühendriikide majanduslik tõusulaine, 20. sajandi alguse venestamispoliitika mõju ja soomlaste värbamine kaevandustesse (Korkiasaari \& Söderling 1994: 251). Pärimusliku ajaloo uurimine on esile toonud väljarände individuaalsemaid põhjusi. Käsitletud materjalis on selleks sageli inimsuhetest tulenevad probleemid: pojad põgenevad Ameerikasse karmi isa eest, südamevaluga vahetati oma maa võõra vastu, kui isa läks teenima perele lisaraha ega tulnudki tagasi. Kirsi Pohjola-Vilkuna (1995: 63) järgi ongi üks Ameerikasse siirdumise olulisi põhjusi abielulahutus, mida juriidiliselt põhjendati abielupoole truudusetuse või abikaasa hülgamisega. Lisaks sellele põgeneti Vene armeesse värbamise eest, mindi teenima maja- või taluostu raha jne. Perelugudes leidub ka ebatavalisi jutustusi:

Ilmari läks Ameerikasse 18-aastaselt ja tal oli seal õnne nii farmerina kui ka pereelus. Ilmselt oli minu emal ja tema poolvennal Ilmaril mingi omavaheline kokkulepe, sest ema juttudest sain aru, nagu oleks vend palunud teda endaga Ameerikasse kaasa. (SKS.SUKU 512, 57-aastane mees). 


\section{Sõjad pere vaatenurgast}

20. sajandi soomlaste ajaloo kujutamisel pärimusjutustuses jätkab väljarände teemat 1918. aasta sõda. Selle kesksemaid motiive on kindlast surmast pääsemine tänu pereliikmest peategelase leidlikkusele. Iseäranis jutustatakse suguvõsa julgetest naistest, kes kinnivõtjate tunnetele rõhudes räägivad vangistatu vabaks. Vabanemise on muuhulgas kaasa toonud ka see, et naine on kiirustanud sündmuspaigale, demonstreerimaks sünnitusvalude algamist. Üks naiste julguse konkreetne põhjus on see, et naine tunneb vangistajat ning loodab sellele, et naabri poeg ei saa tappa naist, keda ta lapsest peale tunneb. Juttude järgi ei ole naised sõjaga silmitsi olles jäänud passiivseteks: Ema tegi parasjagu leiba, kui punakaartlane sisse tuli ja vintpüssi kaba põrandale lõi ning sõnas: "Mina olen rahvavõim. Rahvavõimu nimel võtan need leivad ära, kui need on küpsetatud." Seejärel suunas ta vintpüssi toru ema poole. Ema oli muianud ja sõnanud: "See rahvavõim on küll nõrguke, kui see vaid sinu püssi najal seisab." Mees oli ema sõnadest segadusse sattunud ja pomisenud: "Mind on kästud sedaviisi öelda, muidu ei kuula keegi sõna.» (SKS.SUKU 22180, 70-aastane naine). Eeltoodud näites mõjub sõduri käitumine ebakindlalt ja drillitult. Kodusõja ohvreina kujutatakse siin ka sõjas osalenud noori. Perepärimuse vaatenurgast tuli kodusõda Sise-Soome metsaküladesse kiiresti ja üsna organiseerimatult. Ka sellega kaasa läinud töölisnoored ei mõistnud oma valiku tagajärgi samavõrra kui poliitiliselt aktiivsed töölised. Perepärimuslugudest ilmneb, et tööliste seas oli nii poliitiliselt aktiivseid ja mässu avalikult toetavaid mehi kui ka neid, kes ei kuulunud organisatsioonidesse ja kes meelsamini oleksid algavast sõjast kõrvale jäänud. Jutustustest näeme, et sõjast eemalejäämiseks ei olnud muud võimalust kui liituda metsavendadega. Metsa pagenute elu ei olnud turvaline, kuid kindlasti ahvatles see võimalus mõndagi, kuna teated meelevaldsetest hukkamistest näikse olevat levinud kiiresti. Neist kõneldakse ka perelugudes.
Emaema jutustas, kuidas tema kihluspeol vahetus ootamatult pillimees. Hiljem selgus, et noormees, kes enne mängis, viidi välja ja tapeti. Suvel leiti tema räbaldunud riided põldu piirava aia tagant. Selle sündmusega oligi alanud ümbruskonnas punaste mäss. (SKS.SUKU 6514, 54-aastane naine).

Sõjateemalised jutustused keskenduvad enam koduoludele kui rindele. Sel ajal oli surmaoht õhus kogu aja, iial ei võinud teada, millal see võis tabada lähedast. Jutustuses esitatakse reeglina vaid rindel langenud lähedaste nimed, vanused, hukkumispaik ja rindeloleku aeg. Küll aga peatutakse kodus üleelatud sündmustel. Hukkunu toodi koduouele äratundmiseks ja jumalaga jätmiseks. Sellest jutustatakse läbi hämmeldunud lapsesilmade. Naiste jutustustes assotsieerub sõda vähese viljatagavara, otsatu töö ja söögi nappusega. Kohati said talupered võtta vene sõjavange sulasteks tegema talutöid ajal, mil mehed olid rindel. Olukord näis absurdina: talu perenaine ja vaenlane teevad talus koos tööd samal ajal, kui peremees kaitseb maad sama vaenlase eest. Kodusolijatest pereliikmete seisukohalt ei olnud vangide sulaseks olemine siiski ainult negatiivne, sest abi oli vältimatult vajalik. Asja heaks küljeks on peetud ka seda, et noored õppisid seejuures natuke vene keelt. Järgnevas näites tuleb esile mõlema vanema suhtumine vangidesse. Jutustusest ei selgu küll, kas isa oli kogu aeg kodus või tuli see heakskiit näiteks puhkusel olles või kirjade kaudu. 


\begin{abstract}
Minu vanemad olid oiglase meelega, venelastesse ja ingerlastesse suhtuti heatahtlikult, päris kindlasti oli nende olukord parem kui meie poegadel eesliinil. Kui sõjavangid tuli laagrisse nende väljavahetamiseks tagasi saata, oli valus näha seda kurba minekut. Nad olid harjunud peredega, kõige murelikumaks tegi neid teadmatus tuleviku ees, see pitsitas hinge ja hirmutas. ( SKS.SUKU 1938, 67 aastane naine).
\end{abstract}

Lugejate nagu ka paljude kirjutajate meelest on tuntuim sõjajutustuse motiiv karjalaste evakueerumine Soome eri paikadesse II maailmasõja ajal. Perelood peegeldavad evakueerumist ja sellega kaasnenud erinevate kultuuride kokkupuudet kahest vaatenurgast: kodust lahkujate ja neid oma kodudesse majutanute või külainimeste silme läbi. See aines seostub sõjaga ka nende perede jaoks, kes evakueerumisega vahetult kokku ei puutunud.

Lapsepõlvemälestused sõjast, kuuldud jutud ja läbielatud kaotused ning lood sõjas langenutest toovad isiklikud tunded esile hoopis teisel viisil, kui seda teeb ametlik ajalugu. Sõjast kõrvalehoidmisest jutustav pärimus peegeldab hinnanguid sõjale erinevatest inimlikest vaatepunktidest, näiteks nii sõja eest pakku läinud meeste kui ka koju jäänud omaste läbielamistest, mida pereliikme varjamine omakorda tekitas:
Maria jutustas söögi viimisest kõrvalhoone põranda alla kaevatud auku, otsides kuidas kunagi ajendit hoonesse siseneda. Sõjast kõrvalehoidjat teadagi otsiti ka ametivõimude poolt, kuid teda ei leitud ja nii ta ei sattunud ka sõjakohtu kätte, kuigi mõne korra oli oht lähedalt mööda läinud. (SKS.SUKU 2119, 52-aastane mees).

20. sajandi I pool seostub suurte ühiskondlike muutustega, mis puudutasid iga inimest. 1950. aastatest alates tähistatakse jutustuses aega uudiskaupade tuleku ja muu seesugusega, mis iseloomustab materiaalset heaolu. Sõjajärgsel ülesehitusajal otsiti perede argipäevas uusi orientiire: heaolu kujundati nii ainelises kui ka vaimses maailmas. Raadio muretsemine on mitme vastaja elus saanud märgiks pere käekäigu paranemisest. Paar teadet on selle kohta, kuidas vastaja koju muretsetud küla ainsa raadio juurde kogunesid naabrid uudiseid kuulama. Raadiotele järgnesid televiisorid, külmutuskapid ja autod. 1980. aastate alguses valminud oma maja ja järve kaldale ehitatud suvila mainimine pärast raskete eluperioodide kirjeldamist on soome lugeja jaoks kui märk unelmate täitumisest.

Lähiminevikku kujutatakse perepärimuses üsna aktiivselt. Kuid kui kaugele ajas tagasi ulatub pereloo tundmine? Küsimus on huvitav, kuna aastatuhande vahetus muudab ka 20. sajandi lähiajalooks. Aga varasemad, 19. ja 18., või veelgi kaugemad sajandid? Siin käsitletud materjalis ulatuvad vanematelt ja vanavanematelt saadud pärimusteadmised 19. sajandi keskele, kuigi rõhuasetus jääb 20. sajandil toimunule. Genealoogilise uurimise alal on pere ajalugu rekonstrueeritud 16. sajandini.

\title{
Mida 20. sajandist ei jutustata?
}

Kogus «Suguvõsa suur jutustus» ei leidu jutte sõja eest Rootsi viidud lastest, kuigi 1940. aastate registrite järgi oli Rootsi evakueeritud ligi 70000 last (Korkiasaari, Söderling 1994: 248). Enamik neist olid linnalapsed, peamiselt Helsingist. Vanuselt olid nad enamjaolt 5-8-aastased tööliste peredest pärit lapsed, kuid oli ka tuhandeid alla 4-aastasi ja ka vanemaid, kooliealisi lapsi (Edvarsen 1977: 172-174). (Varakatest peredest pärit lapsed statistikas ei kajastu, sest neid viidi tavaliselt eraviisil sugulaste juurde). 
Miks Rootsi evakueerumisega seotud pärimust on kõnesolevas kogus nii vähe? Vastajate enamik on sündinud 1930.-1940. aastatel, ja seega ea poolest võiksid kuuluda evakueeritute hulka. Aine vähesust selles kogus võisid põhjustada järgmised asjaolud: enamik vastajatest on pärit maalt (evakueeritud lapsed pärinesid peamiselt aga linnadest); mõnedki lastest võisid jääda Rootsi, kuna nad lapsendati seal; osa lapsi olid juba Soomest lahkudes haiged ja paljud neist surid Rootsis. Nooremad lapsed, kes hiljem Soome tagasi tulid, ei mäleta Rootsi viimist, osale lastest oli evakueerumiskogemus liiga ränk, et seda meenutada. On ka arvatud, et raskeim ei olnud mitte Rootsi minek, vaid tagasitulek vaesunud Soome. Evakueerituid vastuvõtnud Rootsi pered olid reeglina majanduslikult heal järjel ning lastele kuulus sellest heaolust oma osa (Edvarsen 1977: 90). Muidugi osutusid probleemiks suhtlemine võõraste inimestega ja võõras keel. Lisaks eeltoodud põhjustele selle teema vähesest kajastumisest kogus «Suguvõsa suur jutustus» on see, et kogumisvõistlust tõlgendati kui jutustusi õnnestumistest, milleks lapsepõlve võõral maal lugeda ei saa. Teisalt võib Soomes eluloojutustuse eeskujuna näha kultuuris juurdunud kujutlust «armetust ja vaesest lapsepõlvest» (tulen hiljem selle juurde tagasi). Sellest lähtuvalt oletan, et ka evakueerumisest oleks võidud jutustada/kirjutada enam. Ka ei saanud see teema kõrvale jääda seetõttu, et seda oleks viimastel aastatel juba kogutud. Selle asemel on see aines leidnud kajastamist fotograafias. Näitused on kindlasti elavdanud mälestusi ja ehk ka pakkunud väljundi nende avaldamiseks eri kultuurivormides. Võrreldes Ameerikasse siirdumise teemaga on Rootsi evakueerunud laste teema suguvõsajuttudes esindatud tagasihoidlikult sellegi tõttu, et Rootsi sattuti lapsena, Ameerikasse mindi noorena või täiskasvanuna.

Soome 20. sajandi sõdadest jäävad analüüsitud materjalist täiesti välja II maailmasõja aegsed sündmused Põhja-Soomes - Lapi sõda. Selle põhjuseks võib olla, et nii kirjanduses kui ka uurijate sõnavõttudes käsitletakse enamasti just teisi sõdu. 1918. aasta kodusõda ja Karjalast lahkumist II maailmasõja ajal tuntakse eri vaatenurkadest kaunis hästi, kuid Lapi sõjast ei räägita põhjasoomlaste pärimusjuttudes peaaegu üldse. Materjalikogu «Suguvõsa suur jutustus» ei sisalda tähelepanu juhtimisest hoolimata Põhja-Soome pärimust sama rikkalikult kui lõunapoolset. Kogumisvõistlusi saatev küsimustik toimib sageli jutustuse raamina. Selles otsest küsimust sõja kohta ei olnud: ainus sõda puudutav küsimus oli: «Mida kõneldakse sõja- ja kriisiaegadest?»

Meie päevil kogutud perepärimus jutustab üsna vähe 19. sajandist ja veel varasemast ajast. 19. sajandi tähelepanuväärseim ajajärk kogu rahva jaoks oli 1860. aastate näljaaeg. Regionaalselt puudutas nälg enamasti Põhja-Soomet, kust näljahädalised rändasid Lõuna-Soome suunas, kus toitu oli rohkem. Esivanematega seotud sündmustest on pärimusi, mis on hetkel jäänud käsitlemata, sest uuritava materjali rõhuasetus on 20. sajandil. Nälja-aastate suremus oli suhteliselt suurem kui II maailmasõja või 1918. aasta sõja ajal (Juva \& Juva 1992: 424). Jutustamiseks sobivat ainest on seega piisavalt; näljaaastaid ongi nimetatud lähiajaloo katastroofilisimaks ajajärguks. Kui jutustuses minnakse ajas enam tagasi ning jutustatava sündmuse vahetu kogeja on jutustaja isa vanaema, siis saab pärimus uue tõlgenduse, kus üht juhtumit võrreldakse teiste analoogsete raskete aegadega:

\footnotetext{
Minu isa jutustas oma vanaemalt Eevalt kuuldud 1870-ndate aastate näljaajast samasuguseid lugusid, nagu neid võib lugeda ajalooraamatutest. Mändide koorimisest petuleiva jaoks, sambla kogumisest, karja hävitamisest, kui neile ei olnud süüa anda, majade õlgkatused söödeti loomadele... Ta oli jutustanud katkust ja teistest taudidest, lumehange külmunud kerjustest. Isa ütles, et küllap see aeg pidi olema kindlasti palju hirmsam kui näiteks 1930-ndate aastate kriisiaastad või II maailmasõja aeg. (SKS.SUKU 235, 65-aastane naine).
} 
Soome 19. sajandi ajalukku kuulub ka Soome sõda (1808-1809), millest siin käsitletud kogus jutte üldse ei ole. Minnes ajas veelgi enam tagasi, 18. sajandisse, on mh jutustatud suure vaenu ajast (1700-1721), mil Peeter I väed tungisid Soome. Edaspidi tehtavas pärimusmaterjali detailsemas analüüsis ja vastajate intervjueerimise abil on kavas täpsemalt välja selgitada, mida perepärimuses teatakse 20. sajandile eelnenud ajast.

Ametliku ajaloo sündmustest jutustamise kõrval kuuluvad perepärimusse kodu siseelu kirjeldused ja argipäev. Järgnevalt sellest, mida soomlased jutustavad koduelust.

\section{Kirjeldused pereelust ja argipäevast}

Enamikul kogumisvõistlusest «Suguvõsa suur jutustus» osavõtnud soomlastel on kogemusi tuumperest suuremast perestruktuurist, kus hommikust õhtuni tehti talutöid, on kogemusi nii suurperes elamisega kaasnevast eraldatusest muust maailmast kui ka kokkukuuluvusest. Neis suguvõsades ja peredes, millest on jutustatud, on kodud üsna pereliikmeid kokkuliitvaks paigaks, kus oma laste ja vanavanemate kõrval kuulus perre sageli ka vallalisi vendi ja õdesid või teisi sugulasi ning orvuks jäänud lapsi. Sageli anti neis kodudes peavarju ka rändtöölistele ja kaupmeestele.

\section{Sageli oli ümbruskonnas üksikuks jäänud kodutuid, peamiselt mehi, kes ei olnud aga joodikud, ja kes käisid talust tallu. -- Nende jaoks oli olemas voodi, kus nad öö magasid, üldiselt läksid nad jälle ära ja üürist sel puhul ei olnud juttugi. Harva pani pererahvas sellist käitumist pahaks. Tava nõudis, et teekäija sai ööbida talus öömaja küsimata. Mõnikord tegid nad talutöidki, kui mõni kingsepp õmbles saapaid või aidati heinatöödel. (SKS.SUKU 11537, 67-aastane mees).}

Eraldatust tolle aja kodudes sel kujul, nagu tänapäeva peredes on, ei tuntud. Kuidas naised räägivad pere argipäevast ja naise kohast tolleaegses elukorralduses? Milliseid rõhuasetusi tehakse suguvõsasisese elu kirjeldamisel? Mis äratab huvi: kas perepärimusjuttudes leidub pilte õnnelikuks olemisest ja headest inimsuhetest? Kas jutustatakse mehe ja naise vahelistest tunnetest? Perepärimuse abielu- ja omavahelise läbikäimise teemalised jutud visandavad pildi pereloomise tavast ja korrast 20. sajandi algupoolel. Kokkuvõtlikult võib öelda, et kaasat ei otsitud kaugelt, et abielu eel ei käidud kaua, kihlasõrmused osteti enam-vähem kindlapeale. Esimene laps saadi kohe pulmadele järgnevatel aastatel, oli tavapärane, et rasedus tuli ilmsiks ruttu pärast abiellumist. Noorpaar asus elama kas mehe koju, kus naine oli minia rollis, või sai abielupaar kodu oma rendikohas.

Milline elu on olnud peredes eriealistel ja erinevates rollides? Naiste juttudes on lapsepõlvemälestused positiivsed, ehkki täis tööd. Karja hoidmine ja kodutööd on kujundanud vastutustunnet, lapseea tegemised on üldse tulevase elu ülesannete harjutamised. Külaühiskonna naiste elustsenaarium on olnud nooruse osas ette määratud; seda on dikteerinud lapsepõlvepere vajadused: oma kodust väljastpoolt otsiti võimalust mööda tööd juba üsna noorena, et suuta kasvavaid õdesid-vendi toita. Koolitusküsimustes ja abikaasavalikus maksis varasemal ajal peamiselt isa sõna.

Materjal annab pereelust üsna sünge pildi. Hingelise läheduse väljendumisele satub lugeja seda otsides, otse sellest ei kõnelda, ja ega neid kirjeldusi arvukalt olegi. Heasüdamliku ja hella lähedasena näidatakse üht kirjutaja vanematest või vanavanematest. Sageli on see ema või vanaema. Abielule pööratakse siinkohal vähem tähelepanu, sageli piirdutakse laste arvu märkimisega. Niisamuti ka meeste juttudes. Naiste juttude järgi on mees sageli muutnud pereelu viletsamaks oma alkoholilembelisuse, vägivaldse käitumise või hingelise heitlikkusega. Mehed seevastu ei kõnele oma naiste vastavatest probleemidest. Tõsi, abieluvälistest suhetest leidub mõningaid märkusi. Järgnev näide esindab harvaesinevat sallivust truudusetuse kujutamisel: 
Saami elukorralduses on armukadeduse mõiste peaaegu tundmatu. Sellest ei ole kära tõstetud, kui laps juhtub olema naabriperemehe nägu. (SKS.SUKU 11538, 67-aastane mees).

Külaühiskonna naiste elu käsitledes kinnitub tahes-tahtmata tähelepanu perede suurele lastearvule ja naiste osale pereelus. Seksuaalsuhete praktika ja naiseks kasvatamine tuleb eriti esile tütarde kasvatusele esitatud hinnangutes ja normides.

Minu lapsepõlves oli kooliskäimine haruldane. Hea oli, kui sai käia rahvakoolis. Selle järel oli tüdrukutel teenijaks minek. Vaid suurte talude tütred said jääda koju kosilast ootama. (SKS.SUKU 8740, 72-aastane naine).

Teenijaks minek tähendas mõnele tüdrukule ka kohanemist talukommetega. Talupoiste ja meeste seas käibis erootiline uhkeldamisekultuur, kuhu kuulus praalimine seksuaalsete alistamistega ja taluteenijatest naiste «läbiproovimisega» ehk seksuaalse "kasutamisõigusega» (Pohjola-Vilkuna 1995: 104-105). Sedalaadi isiklikke suhteid taluperemeestega on nimetatud, kuid sagedamini on sellest räägitud sugulaste kogemuste kau$\mathrm{du}$, ja siiski mitte otse, vaid vihjamisi. Näiteks jutustatakse esmalt peremeeste kombest magada teenijatega, siis aga vanaemast, kes omal ajal vallandati teenijakohalt, ja tema uue teenijakoha otsimisest koos lapsega, millest saab järeldada, mis oli juhtunud. Aastal 1928 sündinud maaharija tütar kujutab naistele suunatud ootusi järgmiselt:

\begin{abstract}
Minu suguvõsas on mehi peetud üldiselt tähtsamateks kui naisi. Naistele on omamoodi osaks saanud elada meeste kaudu ja ohverdada oma elu meeste ning suguseltsi heaks. Kooliharidust ei peetud naiste jaoks vajalikuks. Tuli vaid olla valmis käsi külge lööma iga füüsilise töö juures, tööd valimata ja ilma tasuta. [- -] vallalistel tüdrukutel tuli oma vanemate nõudel püsida kodus tasuta teenijana. (SKS:SUKU 9835, 69-aastane naine).
\end{abstract}

Samasuguseid näiteid leidub uuritud materjalis rohkesti, kusjuures kogemusi ei ole ilustatud:

Tütreid ei hinnatud peredes nii nagu poegi, tüdrukud olid peres nagu prügi. Kui tütar juhtus mehele minema mõnele rikkale, siis ta muutus hinnatumaks. Harva pidas mees oma naist inimeseks. (SKS.SUKU 4698, 71-aastane naine ).

Eespool esitatud näited kodust ja üksikisiku kohast peres toovad uurimisobjektiks argipäeva. Kõnesolevad triviaalsed ja banaalsed seigad, nii-öelda hall argipäev jääb uurijate vaateväljast sageli kõrvale, kuna otsitakse erandlikke ja jõulisi kirjeldusi. Argipäeva tuleks siiski uurida täpsemalt, kuna see on üldiselt vähetuntud. (Vt Lehtonen 1996: 13). Laura Aro (1996: 65) nimetab antropoloogilises ja folkloristlikus uurimises sageli ignoreeritud tavaelujutustuse liikideks muuhulgas raporditaolise jutustuse, klišeelise isiklikel arvamustel ja põhjendustel põhineva kui ka etnoloogilised kirjeldused, mis jäävad tavaliselt analüüsist kõrvale, kuna nad ei ole eriti jutulikud.

Lugedes jutustusi just argipäevanähtustest, tuleb ilmsiks see ulatuslik kultuurimuutus, mis toimus Soome ühiskonnas 20. sajandil. Argipäeva kujutamine toob esile ka tänapäevase kujutluse möödunud aegadest ja tolleaegsest elulaadist. Soome talupojaühiskonna valitsevaks stereotüübiks on peetud piirkondlikku eraldatust ja iseolemise idülli, kujutlust, kus väike vaene rendikoht lasterikka perega ja oma terviklikkusega sümboliseerib raskustest ülesaamist ühise töö ja virkuse abil. Perepärimuse need kirjutajad, kes ise on elanud külaühiskonna argipäevas, võimendavad ühelt poolt pärimuses eelkirjeldatud nostalgilisena näivaid stereotüüpe, kuid samas peegeldub nende pärimuses ka nähtuse teine pool. Iseäranis nende kirjutajate meenutustes, kelle noorusaeg langeb 1950. aastatesse, ilmneb see, mida tähendas argipäeva ja sotsiaalsete suhete tasandil kuulumine linna- või maaühiskonda. Kirjutajad visandavad oma vastustes muuhulgas maal elavate inimeste kujutlusi «ehtsast» linlasest. Selles on nähtav selge 
kadeduse ja vihavärvinguga määratlus meie ja nemad. Samuti arvamused oma kodukohast linna läinute kohta toovad esile maa ja linnaga seonduva mentaliteedi erinevused. Maalt linna läinuid nimetati pakenioitsijoiksi (pagenuteks) ja työtä vieroksuviksi hienostelijoitsijoiksi (tööst võõrdunud keigariteks). Teisalt on linnastumisega seotud võimalus hariduseks ja tööelu edendamiseks, mis soodustab kulutamist ja omandamist. Sugulase hariduseomandamist ja edukust tajuti kui pere ühist au, hoolimata sellest, et see oleks rõhutanud enda koolihariduse vähesust.

\section{Minule hakati tere ütlema just tehnikumi lõpetamise järel ja kui minu poeg oli saanud suguvõsas esimesena valge mütsi, ja see tundus olevat nii ihaluse kui ka halvustava kadeduse asjaks. (SKS.SUKU 3424, 64-aastane mees).}

Perepärimuses kujutatakse oma maasiseste meie - nemad kategooriate kõrval ka suhtumist naaberriiki Venemaasse (Nõukogude Liitu). Soome perepärimuses tulevad soomlaste ja venelaste omavahelised suhted korduvalt esile. Geograafilise asendi tõttu ei ole Soome saanud vältida Venemaal toimunud sündmuste järelkajasid ka iseseisvumisejärgsetel aastakümnetel. Vene on olnud pidevalt kohal ka vaimses plaanis; vanad ütlemised, nagu rüssä on rüssä vaikka voissa paistettais (venelane on venelane, ehkki teda on võis küpsetatud) või venäläistä viekottele, pidä veitsi vierelläsi (venelast meelitades hoia nuga ligi) kõnelevad soomlaste seas valitsevast eelarvamusest venelaste kohta (vt näiteks Kuusi 1954: 54).

Tänapäevase privaatsust toonitava aja nii pere- ja kodukäsitused kui arusaamad argielust osutuvad siinkäsitletud materjalile pereelu kujutamisel vastupidiseks.

Tuumperes elab harva vanavanemaid, teistest sugulastest rääkimata. Sotsiaalne kaugus kahe põlvkonna vahel on kasvanud koos geograafilise kauguse suurenemisega. Pere on eraasi ja ainuüksi juba peretüüpe on praegu erinevaid. Samas püütakse pere- ja tööelu ühitada küll sellega, et pere luuakse vastavalt haridustasemele ja töökohale, kui ka nii, et pereelu ja töö tasakaalustaksid teineteist.

Perepärimusest ongi huvitav otsida neid ilminguid, mis näitaksid, kuidas ollakse kultuurimuutustega kohanetud. Kas maalt linna tulnute elus on võõristustunnet ja kuidas ümberasumist ning muutustega seonduvat tõlgendatakse üksikisiku tasandil? Üleminek tuleb selgemini esile kohaga seotud identiteediilmingutes. Mõnele on kodukoht igatsuste maa; aastakümneid linnas elamine ei tuhmista savolaseks või karjalaseks olemist. Kodukoha külastamisega seonduvaid tundeid kujutatakse muuhulgas näiteks nii, et kohaliku murde kuulmine on märk "oma koju saabumisest». Kirjutistest tuleb esile ka see, et maalt noorena kooli ja töö tõttu linna tulnud ei saa vältida «aja hinge» võrdpilti: sünnib selline kujutlus, kus maalt lahkunud liiguvad kahe maailma vahel, kus varasemad ajad tunduvad lihtsad ja selged: peres kehtis arusaadav ja toimiv pereliikmete omavaheline rollijaotus, ei olnud pidevat tegevuse valimist ega killustumist töö, pere ja vaba aja vahel nagu nüüd. Teisalt nähakse pere ja tööga seotud muutustes seda, et praegune elu läheb põlvkonniti kergemaks.

\section{Esivanematega kokkukuulumistunde muutumine}

Perestruktuuri muutumine on seega suguvõsade kogemusmaailmas veel värskelt meeles. Kuidas teiseneb suguvõsa ja sinna kuulumise tähendus ühiskonna muutumise käigus? Külaühiskonna kultuuris kujunes suguvõsa ühiskondliku arvamuse ja positsiooni mõõdupuuks: suguvõsa mainet pidi iga suguvõsa liige eriti au sees hoidma. Konkreetsemalt ilmneb suguvõsa maine tähendus abiellumisega seotud arusaamades: neiu tuli valida töökast ja auväärsest suguvõsast, peiu väärtust tõstis suguvõsa majanduslik stabiilsus ja tunnustatud ühiskondlik positsioon. 
Käsitletud materjalis võib näha, et suguvõsa maine oli külaühiskonnas avalik asi. Kõik tundsid üksteist ja suguvõsasid võrreldi omavahel nii üldiselt kui ka kosjakauba seisukohalt. Kõneldi sellest, kuidas saaks teatud tallu miniaks, kes jälle sattus abielluma joodikuga või vägivaldse mehega. Vastavalt olukorrale abielu kas avalikustati või vaikiti sellest. Soovimatule kosilasele ja last ootavaile tüdrukutele on püütud ära öelda raha abil.

Kuidas hinnatakse sugulust tänapäeval? Jutustuse varjatumatest tasanditest võib tähele panna, et kehtib lineaarne skeem: peategelaseks kerkib sageli kirjutaja ise, üks tema vanematest või vanavanematest. Memuaarides, eriti naiste kirjutatuis, ei tõrjuta naisi kõrvale nagu traditsioonilises suguvõsapärimuses. Raskusi naisliinide jälgimisel põhjendatakse ajalooallikate ebasobivusega selleks tööks ning naiste osa meestega võrreldes vähendatakse mainimiseks. (Siukonen, Timo (1998): Naisi ignoreeritakse suguvõsauurimustes. - Helsingin Sanomat 3.8.1998. Artiklis viidatakse rahvakultuuri uurija Sanna-Kaisa Spoofi ettekandele). Siinkäsitletud materjalis, eriti meeste kirjutistes, ei loeta tütardest järglasi suguvõsa jätkajateks. Ka Eestis on esile tõstetud meestekeskset jutustust: esiisadest teatakse enam ja ajas kaugemale kui naistest (Jaago \& Jaago 1996: 129).

Arusaam soo jätkumisest meesliini pidi pärineb sellest, et tütardest sündinud lapsed kannavad oma isa perekonnanime ja tütardepoolsetes järeltulijates ei jätku seega sugulus perekonnanime kaudu. On imekspandav, et perekonnanime ja meesliiniga seotuses olevat sugulust peetakse määravaks. Kas soo jätkumine tütarde kaudu ei seostu kuidagi järeltulija geenide, omaduste või välimusega?

Meeste koostatud pereajaloole on omane suguvõsa juurte otsimine lähtuvalt elukohast, hõimupiiride selgitamine, talumaade omandi- ja pärimissuhted, aga ka esiisa leidmine. Esiisa, kelleks on tavaliselt autoriteetseks peetud mees, püütakse leida ajas võimalikult kaugelt. Näiteks on selleks genealoogilises uurimuses valitud 16. sajandil Nuiasõja ajal (1596-1599) vaimulikuna tegutsenud mees, kes on proovinud kaitsta talupoegi. Naiste jutustustes kerkivad esivanematena esile argipäeva-kangelased, lihtsad pereemad ja -isad, kes ühel või teisel moel toidavad ja katavad oma suure pere ära ja saavad hakkama raskustega. Lisaks sellele keskendub naiste jutustus suguvõsasiseste suhete kujutamisele ja ka oma vanemate elujärkude rekonstruktsioonile.

Perekonnanime algupäraga liituvaid selgitusi käesolevalt uuritud materjalis eriti esile ei tule. Erandiks on näide, kus perekonnanime päritolu tõlgendatakse üllatavalt müütilisena:

...on olemas jutustusi, kus öeldakse, et kõik Pulkkised ei olegi sugulased, vaid et nad olla olnud algaegadel kogukond, hõim või mingi vastav rahvakild. Nimi oli tulnud pulgast või mingist teivast meenutavast esemest. Too sau olnud mingil ajal ka hõimu tunnuseks. (SKS.SUKU 22988, 73-aastane mees).

1990. aastatel räägitud juurte puudumisest või kodukohaga kokkukuulumatusest leidub ka selles ainestikus viiteid. Näiteks teise põlve pagulaskarjalane ütleb end olevat «oma kohata maailmarahvas», kellele kuuldud jutustused Karjalast on avaldanud tugevat mõju, ja ehkki ta ei ole Karjalas kunagi käinud, märkab ta, et ta igatseb sinna nagu ta vanemadki. Tema järgi «juurte» kujunemise üks tingimus on see, et vanem põlvkond näitab noorematele põlvedele konkreetset perega seotud ajalugu: talumaid ja hooneid või muid paiku, millega seostuvad kuuldud jutud elust-olust. Juurtetust tunnevad siiski teisedki kui karjalaste järglased. Mõnele ei ole pere minevikust räägitud, sageli on nii, et noori see ei huvita ja vanemaks saades, kui huvi tärkab, on jutustajad-teadjad juba surnud. 
Pere tähendus ja lähedus on tänapäeval üsna individuaalne, ehkki selge joonena võib esile tuua seda, et vananedes kasvab ka huvi oma päritolu vastu. Noorte elus on päritolu probleemi korvanud sõprade ja muude väikeste rühmade olemasolu. Samas aga tugevdatakse oma pere kokkukuuluvust ja traditsioone. Huvitavaks ilminguks on siin interneti perealbumid, kus multimeedia kaudu esitatakse privaatsfääri kuuluvat: vaataja ees on näha pildid kodumajast, pereliikmete pilte täiendavad jutustused nende tegevusest, salvestatud on laste laul. (Näiteks sõnaotsingu «family albums» kaudu) Üksikud, kuid üllatavalt tugevad mõtteavaldused kõnelevad suguvõsa ühtsuse tähtsaks pidamise kõrval ka privaatsuse ja kokkukuuluvuse tasakaalust, nagu näiteks järgnevas lauses:

Ma olen alati tundnud, et kuulun suguvõssa, olen selle liige ja sõltun sellest. (SKS.SUKU 6518, 54-aastane naine).

Tõlkinud Tiiu Jaago

Autor tänab lahkete konsultatsioonide eest Aino Laagust ja Tiia Kössi

\section{Vaata veel:}

- Tiiu Jaago kommentaar "Ääremõtteid Pauliina Latvala artiklile «Soomlase elu kujutamine pärimuslikus ajaloos»"

- Ene Kõresaare kommentaar "Pauliina Latvala «Soomlase elu kujutamine pärimuslikus ajaloos»"

Lingid novembrist 1999, hilisemate muutuste eest linkide sees toimetus ei vastuta.

\section{Kirjandus}

Apo, Satu 1995. Naisen väki: tutkimuksia suomalaisten kansanomaisesta kulttuurista ja ajattelusta. Helsinki.

Aro, Laura 1996. Minä kylässä. Identiteettikertomus haasttatelututkimuksen folklorena. Helsinki.

Edvarsen, Annu 1977. Sotalapset. Jyväskylä.

Haapala, Pertti 1992. Suomalainen yhteiskunta. Itsenäistymisen vuodet 1917-1920. 3.

Katse tulevaisuuteen. Helsinki.

Hareven Tamara 1994. Recent Research on the History of the Family. Time, Family and Community. Cambridge.

Jaago, Tiiu \& Jaago, Kalev 1996. See olevat olnud... Rahvaluulekeskne uurimus esivanemate lugudest. Tartu.

Juva, Einar W. \& Juva, Mikko 1992. Suomen kansan historia. III. Ruotsin ajan loppukausi. Helsinki.

Knuuttila, Seppo 1994. Tyhmän kansan teoria. Näkökulmia menneestä tulevaan. Helsinki.

Korkiasaari, Juoni \& Söderling, Ismo 1994. Muuttoliike. Suomen Väestö. Hämeenlinna. 
Mäetagused 111999

Kuusi, Matti 1954. Sananlaskut ja puheenparret. Helsinki.

Lehtonen, Mikko 1996. Merkitysten maailma: kulttuurisen tekstintutkimuksen lähtökohtia. Tampere.

Peltonen, Ulla-Maija 1996. Punakapinan muistot. Tutkimus työväen muistelukerronnan muotoutumisesta vuoden 1918 jälkeen. Helsinki.

Pohjola-Vilkuna, Kirsi 1995. Eros kylässä. Maaseudun luvaton seksuaalisuus vuosisadan vaihteessa. Helsinki.

Siukonen, Timo 1998. Naisia syrjitään sukututkimuksessa. Helsingin Sanomat 3.08.1998.

Spoof, Sanna-Kaisa 1994. Sukuseurojen perustamisen aaltoliikettä. Sukuviesti nr 6. 1994. 